\title{
Pengaruh Lingkungan Keluarga Terhadap Pembentukan Tingkah Laku Anak
}

\author{
Marfuatun*1, Yosi Nur Kholisho*2, Nisa Afifah ${ }^{3}$ \\ marfuatun.bkhamzanwadi@gmail.com ${ }^{* 1}$,yosink.peninfo@gmail.com² \\ nisa.afifah123@iainsalatiga.ac.id ${ }^{3}$ \\ 1,2Universitas Hamzanwadi, ${ }^{3}$ IAIN Salatiga
}

Received: Juni 2020

Accepted: Juni 2021

Online Published: Juli 2021

\begin{abstract}
Education through activities outside of school is a learning activity that does not require tiered and continuous activities. The family is the main foundation that can influence the attitudes and behaviour of a child. Children's behaviour includes attitudes, speech, actions and perceptions of children in the development process so that they become a character. The character appears through thoughts obtained based on experience and observations from where a person grows and develops, starting from the first meaning that is understood based on a person's words, gestures and behaviour. This study aimed to determine the influence of the family environment on the formation of children's character. The method used is descriptive quantitative, with a correlational study approach. After testing the hypothesis, which reads: 'there is an influence of the family environment on the formation of children's behaviour', it was found that the hypothesis is acceptable, meaning that the family environment has an effect of $13.8 \%$. These results indicate an influence of the family environment on the formation and changes in children's behaviour. The family is the initial foundation for children to interact with the outside environment, living environment and the school environment.
\end{abstract}

Keyword: Family Environment, Behavior, Children

\begin{abstract}
Abstrak
Pendidikan melalui kegiatan diluar sekolah merupakan kegiatan pembelajaran yang tidak membutuhkan kegiatan berjenjang serta berkesinambungan. Keluarga menjadi pondasi utama yang dapat mempengaruhi sikap dan prilaku seorang anak. Prilaku anak meliputi sikap, ucapan, tindakan serta persepsi anak di dalam proses perkembangannya sehingga menjadi sebuah karakter. Karakter tersebut muncul melalui pemikiran yang diperoleh berdasarkan pengalaman dan pengamatan dari dimana seseorang tersebut tumbuh dan berkembang, mulai dari makna pertama yang dipahami berdasarkan kata, isyarat dan tingkah laku seseorang. Tujuan dari penelitian ini adalah mengetahui pengaruh lingkungan keluarga terhadap pembentukan karakter anak. Metode yang digunakan adalah deskriptif kuantitatif, dengan pendekatan studi korelasional. Setelah dilakukan pengujian terhadap hipotesis yang berbunyi: 'ada pengaruh lingkungan keluarga terhadap pembentukan tingkah laku anak', ditemukan hasil bahwa hipotesis tersebut dapat diterima artinya lingkungan keluarga memberikan pengaruh sebesar 13,8\%. Hasil tersebut menunjukkan terdapat pengaruh lingkungan keluarga terhadap pembentukan dan perubahan tingkah laku anak, keluarga menjadi pondasi awal untuk anak dapat beriteraksi dengan lingkungan luar baik itu lingkungan tempat tinggal maupun lingkungan sekolah,
\end{abstract}

Kata kunci: Lingkungan Keluarga, Tingkah Laku, Anak 


\section{Educatio: Jurnal IImu Kependidikan}

Vol. 16, № 1 Juli 2021, hal. 71-79

http://e-journal.hamzanwadi.ac.id/index.php/edc

e-ISSN: 2527-9998

DOI: 10.29408/edc.v16i1.3610

\section{PENDAHULUAN}

Sumber daya manusia dapat meningkat salah satunya melalui pendidikan, Pendidikan menjadi faktor dalam berkebangnya sumber daya manusia karena pendidikan mampu menciptakan dan meningkatkan manusia produktif (Kunaryo, 2000). Pendidikan pada dasarnya merupakan kegiatan yang dapat dilaksanakan dimana saja, dalam arti luas pendidikan dalam proses penyelenggaraan dibagi menjadi dua, yaitu melalui sekolah dan luar sekolah. Pendidikan tidak akan berjalan dengan baik tanpa adanya proses belajar yang terus menerus atau berkesinambungan (Putro, 2020). Tujuannya untuk mencapai hasil belajar siswa/anak baik dalam pelajaran disekolah dan non pembelajaran yang bermuara pada kesiapan anak memasuki kompetisi atau persaingan hidup (Kholisho, 2018). Selain hal tersebut pendidikan dinilai untuk mendorong seseorang berbuat positif dalam kehidupan (Susiati, 2021).

Pendidikan luar sekolah salah satu pelaksanaannya yaitu melalui pendidikan keluarga untuk memberikan pemahaman atau pendidikan tentang agama, nilai budaya, dan keterampilan (Depdiknas, 2003). Keluarga menjadi pondasi utama yang dapat mempengaruhi sikap dan prilaku seorang anak. Sehingga dapat disimpulkan pendidikan bukan saja menjadi tanggung jawab sekolah akan tetapi pendidikan juga terjadi dan menjadi tanggung jawab pada lingkup keluarga (Kholisho, 2020).

Prilaku anak meliputi sikap, ucapan, tindakan serta persepsi anak di dalam proses perkembangannya sehingga menjadi sebuah karakter. Karakter tersebut muncul melalui pemikiran yang diperoleh berdasarkan pengalaman dan pengamatan dari dimana seseorang tersebut tumbuh dan berkembang, mulai dari makna pertama yang dipahami berdasarkan kata, isyarat dan tingkah laku seseorang. Peran keluarga khususnya orang tua sebagai pendamping, guru, motifator, teman dalam proses belajar serta membentuk karakter sehingga anak mendapatkan pembelajaran sikap dan tingkah laku yang akan terus berkembang yang dimulai dari rumah (Indramawan, 2020).

Pengamatan awal yang telah dilakukan memperlihatkan adanya prilaku anak yang berbeda-beda, ada anak yang terlihat pendiam, cuek, ceria, pemarah. Prilaku tersebut terlihat saat dilakukan observasi serta dilakukan tanya jawab kepada anak-anak. Bahkan sikap dan tingkah-laku anak dengan latar belakang profesi keluarga pun terlihat berbeda. Berdasarkan temuan tersebut terdapat penelitian tentang Pengaruh Kondisi Ekonomi Keluarga terhadap Perilaku Anak Didik yang menunjukkan hasil bahwa tidak ada pengaruh yang signifikan dari kondisi ekonomi keluarga terhadap perilaku siswa, dan penelitain yang berjudul Kontribusi Kondisi Lingkungan Orang Tua terhadap Tingkah Laku pada Siswa menunjukkan bahwa ada pengaruh kondisi lingkungan keluarga terhadap tingkah laku anak didik adalah benar dan dapat diterima. Kedua penelitian tersebut terdapat perbedaan hasil dengan muara yang ingin dicapai hamper sama. Sehingga perlu dilakukan pengkajian tambahan untuk mencari hasil berdasarkan 
permasalahan tersebut. Tujuan dari penelitian ini adalah mengetahui pengaruh lingkungan keluarga terhadap pembentukan karakter anak.

\section{METODE PENELITIAN}

Metode yang digunakan adalah deskriptif kuantitatif, dengan pendekatan studi korelasional. Penelitian ini dilakukan pada warga atau anak di lingkungan kecamatan selong, dengan sampel anak di kelurahan sekarteja dan sandubaya. Variabel dalam penelitian ini terdiri dari 2 variabel: variabel bebas yaitu kondisi lingkungan keluarga sedangkan variabel terikat yaitu tingkah laku anak.

Hipotesis yang digunakan: ada pengaruh lingkungan keluarga terhadap pembentukan tingkah laku anak. Instrumen data yang digunakan angket, berikut penjabaran berdasarkan variabel penelitian:

Tabel 1. Tabel Kisi-Kisi Instrumen Lingkungan Keluarga dan Tingkah Laku

\begin{tabular}{|c|c|c|c|}
\hline Variabel & Aspek-Aspek & Indikator & $\begin{array}{c}\text { Jumlah Item } \\
\text { Pernyataan }\end{array}$ \\
\hline \multirow{9}{*}{$\begin{array}{l}\text { Lingkungan } \\
\text { Keluarga }\end{array}$} & Pendidikan Orang Tua & Cara Mendidik Anak & 2 \\
\hline & & Memberikan Pemahaman & 2 \\
\hline & & Pola Asuh Orang Tua & 2 \\
\hline & Aktifitas Orang Tua & Pekerjaan Orang Tua & 1 \\
\hline & & $\begin{array}{l}\text { Kurangnya } \\
\text { pengawasan dari orang tua } \\
\text { karena aktivitas jauh dari } \\
\text { rumah }\end{array}$ & 1 \\
\hline & & $\begin{array}{l}\text { Membantu Pekerjaan Orang } \\
\text { Tua }\end{array}$ & 2 \\
\hline & Status Sosial Ekonomi & $\begin{array}{l}\text { Tingkat Pendapatan Orang } \\
\text { Tua }\end{array}$ & 1 \\
\hline & & Biaya Pendidikan Terpenuhi & 1 \\
\hline & & Sarana Belajar Tersedia & 3 \\
\hline \multirow[t]{6}{*}{ Tingkah Laku } & Berjalan & Berjalan dengan Apa Adanya & 1 \\
\hline & & Berlenggak Lenggok & 1 \\
\hline & Berbicara & Sikap dalam Berbicara & 1 \\
\hline & & $\begin{array}{l}\text { Bersikap Sopan dalam } \\
\text { Berbicara dengan Orang yang } \\
\text { Lebih Tua dan Teman }\end{array}$ & 1 \\
\hline & Bereaksi & $\begin{array}{l}\text { Bereaksi Positif Terhadap } \\
\text { Suatu Keadaan }\end{array}$ & 1 \\
\hline & & Bersikap Negatif & 1 \\
\hline
\end{tabular}




\begin{tabular}{|c|c|c|c|}
\hline $\mathcal{U}$ & & \multicolumn{2}{|c|}{$\begin{array}{r}\text { Educatio: Jurnal IImu Kependidikan } \\
\text { Vol. 16, } \mathcal{N} \text { O } 1 \text { Juli 2O21, hal. } 71-79 \\
\text { http://e-journal.hamzanwadi.ac.id/index.php/edc } \\
\text { e-ISSN: 2527-9998 } \\
\text { DOI: 10.29408/edc.v16i1.3610 }\end{array}$} \\
\hline & Berpakaian & $\begin{array}{ll}\text { Selalu Berpakaian } & \text { Sesuai } \\
\text { dengan Sopan } & \\
\text { Mencari Perhatian } & \text { dengan } \\
\text { Cara Berpakaian } & \end{array}$ & $\begin{array}{l}1 \\
1\end{array}$ \\
\hline & Berfikir & $\begin{array}{l}\text { Berfikir Kreatif dan Inovatif } \\
\text { Berfikir Rasional dan Empiris }\end{array}$ & $\begin{array}{l}1 \\
1\end{array}$ \\
\hline & Berpersepsi & $\begin{array}{l}\text { Memberikan Arti terhadap } \\
\text { Lingkungan } \\
\text { Berpandangan Baik terhadap } \\
\text { Lingkungan dan Orang-Orang } \\
\text { Sekitar }\end{array}$ & $\begin{array}{l}1 \\
1\end{array}$ \\
\hline & \multirow[t]{2}{*}{ Emosi } & $\begin{array}{l}\text { Memiliki Emosi yang Stabil } \\
\text { Mampu Menahan Emosi } \\
\text { dalam Keadaan Apapun }\end{array}$ & $\begin{array}{l}1 \\
1\end{array}$ \\
\hline & & $\begin{array}{l}\text { Memiliki Emosi yang } \\
\text { Meledak-Ledak }\end{array}$ & 1 \\
\hline
\end{tabular}

\section{HASIL DAN PEMBAHASAN}

Penelitian dilakukan dengan menyebarkan angket kepada 30 orang anak tanpa memandang usia yang berkisar mulai dari usia 11 tahun hingga 17 tahun mulai jenjang sekolah dasar(SD) hingga sekolah menengah atas (SMA) yang berada disekitar Kelurahan Sekarteja dan Kelurahan Sandubaya. Angket yang diberikan dibuat dalam bentuk cetak dan online, angket online dibuat dengan berbantu google form. Dibentuk dalam dua jenis ini didasari oleh hamper semua anak saat ini sudah dibekali dengan gawai atau sering disebut dengan gatged bahkan banyak anak-anak yang bahkan tidak bisa jauh dari gatget sedangkan untuk cetak diperuntukkan bagi anak yang tidak dibekali gatged oleh orang tua.

Berdasarkan hasil olah data dengan diperoleh hasil bahwa:

Perhitungan pengaruh lingkungan keluarga terhadap pembentukan tingkah laku anak:

\section{a. Pengaruh Lingkungan Keluarga}

Skor maximal ideal : $15 \times 4=60$

Skor minimum ideal : 15 x $1=15$

Skor rata-rata $: 43,3$

$\mathrm{N}: 30$

$\mathrm{Mi}=1 / 2($ skor $\max +$ skor $\min )$

$=1 / 2(60+15)$

$=1 / 2(75)$

$=37,5$

$\mathrm{Sdi}=$.(skor max - skor min)

$=(60-15)$ 
$=.(45)$

$=7,5$

Dengan demikian, pengkategorian pengaruh lingkungan Keluarga siswa dapat disajikan sebagai berikut ini:

1) $\mathrm{Mi}+1 \mathrm{SDi}-\mathrm{Mi}+3 \mathrm{SDi}=$ Tinggi

$37,5+1(7,5)-37,5+3(7,5)$

$45-60$

2) $\mathrm{Mi}-1 \mathrm{SDi}-\mathrm{Mi}+1 \mathrm{SDi}=$ Sedang

$37,5-1(7,5)-37,5+1(7,5)$

$30-45$

3) $\mathrm{Mi}-3 \mathrm{SDi}-\mathrm{Mi}-1 \mathrm{SDi}=$ Rendah

$37,5-3(7,5)-37,5-1(7,5)$

$15-30$

Berdasarkan hasil pengkategorian diatas, maka pengaruh kondisi lingkungan keluarga sebagai berikut:

Tabel 2. Kategori Kondisi Lingkungan Keluarga

\begin{tabular}{ccl}
\hline $\begin{array}{c}\text { Nama Anak } \\
\text { (Disamarkan) }\end{array}$ & Skor & Kategori \\
\hline Anak 1 & 49 & Tinggi \\
Anak 2 & 49 & Tinggi \\
Anak 3 & 47 & Tinggi \\
Anak 4 & 48 & Tinggi \\
Anak 5 & 43 & Sedang \\
Anak 6 & 44 & Sedang \\
Anak 7 & 46 & Tinggi \\
Anak 8 & 46 & Tinggi \\
Anak 9 & 43 & Sedang \\
Anak 10 & 47 & Tinggi \\
Anak 11 & 44 & Sedang \\
Anak 12 & 39 & Sedang \\
Anak 13 & 47 & Tinggi \\
Anak 14 & 45 & Tinggi \\
Anak 15 & 45 & Tinggi \\
Anak 16 & 48 & Tinggi \\
Anak 17 & 39 & Sedang \\
Anak 18 & 48 & Tinggi \\
Anak 19 & 47 & Tinggi \\
Anak 20 & 44 & Sedang \\
Anak 21 & 38 & Sedang \\
& & \\
\hline
\end{tabular}




\begin{tabular}{lcl} 
Anak 22 & 45 & Tinggi \\
Anak 23 & 35 & Sedang \\
Anak 24 & 43 & Sedang \\
Anak 25 & 34 & Sedang \\
Anak 26 & 43 & Sedang \\
Anak 27 & 43 & Sedang \\
Anak 28 & 25 & Rendah \\
Anak 29 & 43 & Sedang \\
Anak 30 & 41 & Sedang \\
\hline Jumlah & $\mathbf{1 2 9 8}$ & \\
Nilai Rata-Rata & $\mathbf{4 3 , 3}$ & Sedang
\end{tabular}

. KATEGORI KONDISI LINGKUNGAN KELUARGA

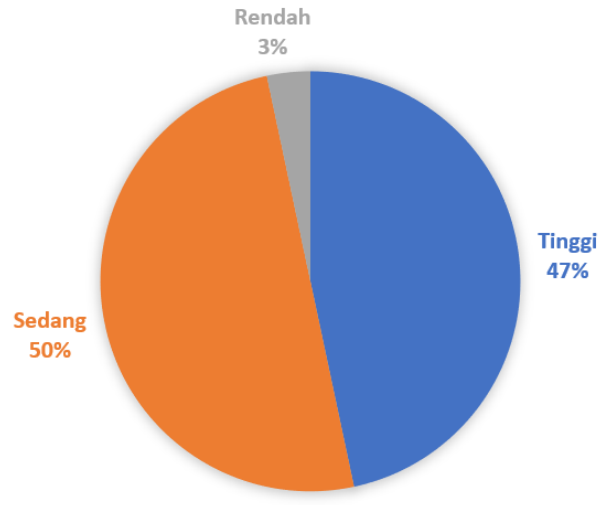

Gambar 1. Chart Kategori Kondisi Lingkungan Keluarga

\section{b. Pembentukan Tingkah Laku}

Skor maximal ideal : 60

Skor minimum ideal : 15

Skor rata-rata : 45,1

$\mathrm{N}: 30$

Berdasarkan hasil pengkategorian, maka pembentukan tingkah laku sebagai berikut:

Tabel 3. Kategori Pembentukan Tingkah Laku

\begin{tabular}{lcc}
\hline $\begin{array}{c}\text { Nama Anak } \\
\text { (Disamarkan) }\end{array}$ & Skor & Kategori \\
\hline Anak 1 & 44 & Sedang \\
Anak 2 & 49 & Tinggi \\
Anak 3 & 53 & Tinggi \\
Anak 4 & 44 & Sedang \\
Anak 5 & 52 & Tinggi \\
Anak 6 & 42 & Sedang
\end{tabular}




\begin{tabular}{lcc} 
Anak 7 & 45 & Tinggi \\
Anak 8 & 52 & Tinggi \\
Anak 9 & 49 & Tinggi \\
Anak 10 & 52 & Tinggi \\
Anak 11 & 47 & Tinggi \\
Anak 12 & 52 & Tinggi \\
Anak 13 & 51 & Tinggi \\
Anak 14 & 57 & Tinggi \\
Anak 15 & 50 & Tinggi \\
Anak 16 & 45 & Tinggi \\
Anak 17 & 51 & Tinggi \\
Anak 18 & 46 & Tinggi \\
Anak 19 & 39 & Sedang \\
Anak 20 & 46 & Tinggi \\
Anak 21 & 31 & Sedang \\
Anak 22 & 34 & Sedang \\
Anak 23 & 41 & Tinggi \\
Anak 24 & 49 & Tinggi \\
Anak 25 & 37 & Sedang \\
Anak 26 & 35 & Sedang \\
Anak 27 & 41 & Sedang \\
Anak 28 & 38 & Sedang \\
Anak 29 & 38 & Sedang \\
Anak 30 & 44 & Sedang \\
\hline Jumlah & $\mathbf{1 3 5 4}$ & \\
Nilai Rata-Rata & $\mathbf{4 5 , 1}$ & Tinggi \\
\hline
\end{tabular}

KATEGORI PEMBENTUKAN TINGKAH LAKU

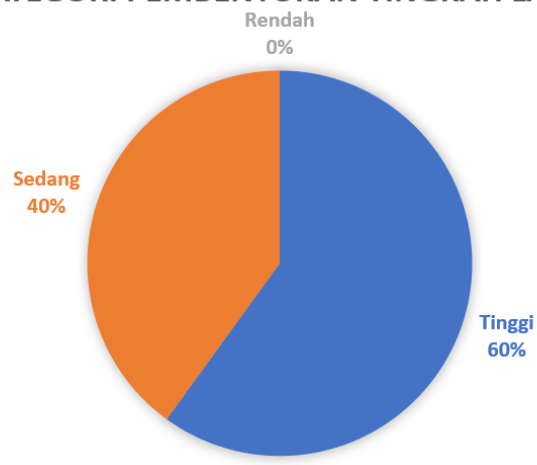

Gambar 2. Chart Kategori Pembentukan Tingkah Laku

\section{c. Pengujian Hipotesis}

Berdasarkan hasil analisis, di peroleh $r$ hhitung $>\mathbf{r}$ tabel $(0,372>0,367)$ dan $r 2=0,138$ artinya lingkungan keluarga memberikan pengaruh sebesar 13,8\%. Jadi Ha diterima dan Ho 
ditolak pada taraf signifikansi $5 \%$ dengan derajat kebebasan $(\mathrm{dk})=\mathrm{N}-1=30-1=29$. Dari analisis tersebut terlihat bahwa pengujian dilakukan angka rata-rata (mean) dari kelompok sampel yaitu diperoleh $\mathbf{r}$ _hitung $=0,372$ dan $r \_$tabel $=0,367$ pada taraf signifikansi 5\% dengan $\mathrm{dk}=\mathrm{n}-1=30-1$. Jadi $\mathrm{r}$ _hitung $>$ r_tabel, maka hipotesis alternatif (Ha) diterima dan hipotesis statistik (Ho) ditolak. Berdasarkan hasil tersebut dapat disimpulkan, adanya pengaruh lingkungan keluarga terhadap pembentukan tingkah laku anak.

Berdasarkan hasil perhitungan dapat dikatakan sedang karena hanya tidak semua yang memiliki lingkungan keluarga yang baik, ada yang merasa memiliki lingkungan keluarga yang cukup saja tidak baik dan tidak juga rendah. Berdasarkan hasil perhitungan tingkah laku diperoleh simpulan berkatagori tingkah laku tinggi walaupun tidak besar persentase yang diperoleh akan tetapi tidak ditemukan kategori tingkah laku rendah.

Setelah dilakukan pengujian terhadap hipotesis yang berbunyi: 'ada pengaruh lingkungan keluarga terhadap pembentukan tingkah laku anak', ditemukan hasil bahwa hipotesis tersebut dapat diterima artinya lingkungan keluarga memberikan pengaruh sebesar 13,8\%. Dengan demikian, Ha diterima dan pada taraf signifikan 5\% dengan drajat kebabasan 29. Secara teoritis, fenomena ini dapat dijelaskan, lingkungan keluarga mencakup bagaimana keadaan yang ada dalam keluarga sehingga baik ataupun buruknya tingkah laku anak pada saat awal masuk ke lingkungan sekolah maupun lingkungan masyarakat yang menjadi pondasi utama adalah keluarga.

\section{SIMPULAN}

Berdasarkan hasil penelitian tersebut menunjukkan bahwa terdapat pengaruh lingkungan keluarga terhadap pembentukan dan perubahan tingkah laku anak, keluarga menjadi pondasi awal pada anak untuk dapat beriteraksi dengan lingkungan luar baik itu lingkungan tempat tinggal maupun lingkungan sekolah, akan tetapi berdasarkan hasil penelitian besarnya persentase tidak begitu signifikan, sehingga dapat dikatakan adanya faktor lain juga yang mempengaruhi tingkah laku anak. Hal tersebut menunjukkan perlunya adanya penelitiaan lanjutan untuk melihat faktor-faktor apa saja yang mempengaruhi pembentukan dan perubahan tingkah laku seorang anak. Penelitian ini dapat saja berbeda pada situasi dan lingkungan yang lain.

\section{PERNYATAAN PENULIS}

Penulis menyatakan bahwa artikel ini belum pernah diterbitkan dalam jurnal manapun

\section{DAFTAR PUSTAKA}

Depdiknas. 2003. Undang-undang Pendidikan Nasional Nomor 20 Tahun 2003. Jakarta Indramawan, A. (2020). Pentingnya Pendidikan Karakter dalam Keluarga Bagi Perkembangan Kepribadian Anak. J-KIs: Jurnal Komunikasi Islam, 1(1). 


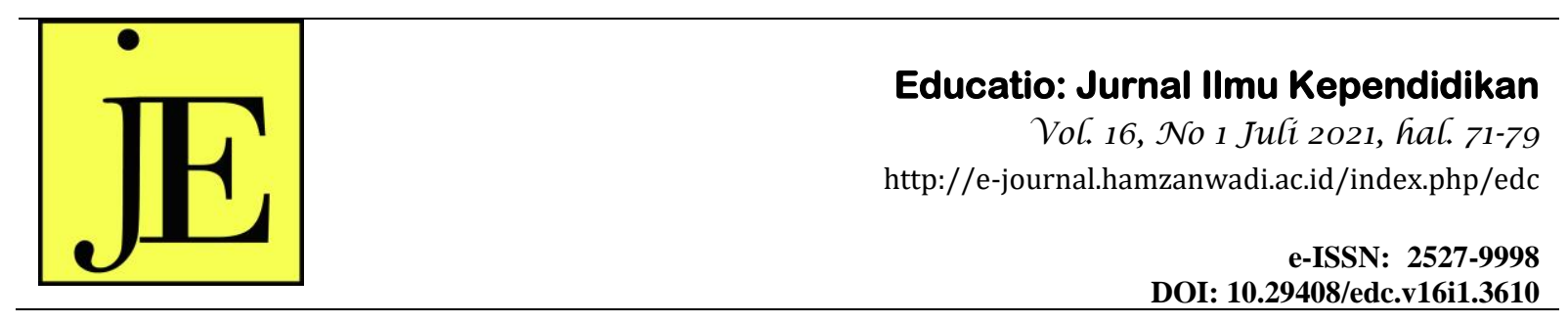

Kunaryo, (1999). Pengantar Pendidikan. Semarang: IKIP Semarang PRESS

Putro, K. Z., Amri, M. A., Wulandari, N., \& Kurniawan, D. (2020). Pola interaksi anak dan orangtua selama kebijakan pembelajaran di rumah. Fitrah: Journal of Islamic Education, 1(1), 124-140.

Susiati, S., Masniati, A., \& Iye, R. (2021). Kearifan Lokal Dalam Perilaku Sosial Remaja Di Desa Waimiting Kabupaten Buru. Sang Pencerah: Jurnal Ilmiah Universitas Muhammadiyah Buton, 7(1), 8-23.

Kholisho, Y. N., \& Marfuatun, M. (2020). Daya Serap Pelaksanaan Mata Kuliah Kependidikan di Tengah Pandemi Covid-19. Edumatic: Jurnal Pendidikan Informatika, 4(1), 131-140.

Kholisho, Y. N., \& Marfuatun, M. (2018). Implementasi Kurikulum 2013 Pada SMK di Kabupaten Lombok Timur. Edumatic: Jurnal Pendidikan Informatika, 2(2), 120-127. 